Artikel Penelitian

\title{
Formulasi Tiwul Instan Tinggi Protein dari Tepung Ubi Kayu yang Disubstitusi Tepung Koro Pedang dan Susu Skim
}

Formulation of High Protein-Instant Tiwul Made from Cassava Flour Substituted Jack Bean Flour and Skimmed Milk

Friska Citra Agustia ${ }^{1 *}$, Herastuti Sri Rukmini ${ }^{2}$, Rifda Naufalin $^{2}$

${ }^{1}$ Program Studi IImu Gizi, Fakultas IImu-IImu Kesehatan, Universitas Jenderal Soedirman, Purwokerto

${ }^{2}$ Prodi Ilmu dan Teknologi Pangan, Fakultas Pertanian, Universitas Jenderal Soedirman, Purwokerto

*Korespondensi dengan penulis (furissuka@yahoo.co.id)

Artikel ini dikirim pada tanggal 24 Januari 2018 dan dinyatakan diterima tanggal 28 Februari 2018. Artikel ini juga dipublikasi secara online melalui www.jatp.ift.or.id. Hak cipta dilindungi undang-undang. Dilarang diperbanyak untuk tujuan komersial.

Diproduksi oleh Indonesian Food Technologists $®$ @ 2018

\section{Abstrak}

Penelitian bertujuan untuk menentukan formula dan karakter tiwul instan terbaik yang dibuat dari tepung mocaf dengan substitusi tepung koro pedang dan susu skim. Rancangan penelitian menggunakan rancangan acak kelompok. Faktor perlakuan terdiri dari proporsi tepung ubi kayu : tepung koro pedang : susu skim $(\mathrm{P} ; \mathrm{b} / \mathrm{b}) \mathrm{P} 1=80$ $: 15: 5, \mathrm{P} 2=70: 25: 5, \mathrm{P} 3=60: 35: 5$ dan modifikasi tepung ubi kayu $(\mathrm{A})$ yaitu $\mathrm{A} 0=$ tanpa modifikasi dan $\mathrm{A} 1=$ modifikasi dengan ragi tape. Variabel yang dianalisis adalah sifat fisikokimia (kadar air, kadar abu, kadar lemak, kadar protein dan koefisien rehidrasi) dan sifat sensori (tekstur, rasa kacang, flavor dan kesukaan) yang diujikan kepada 25 panelis semi terlatih. Data dianalisis dengan Uji F (anova) dan dilanjutkan dengan DMRT (Duncan Multiple Range Test). Perlakuan terbaik berdasarkan uji indeks efektifitas adalah P3A0 (tepung ubi kayu-tepung koro pedangsusu skim $60: 35: 5$, tanpa modifikasi) memiliki kandungan protein 8,84\%bk; lemak 1,66 \%bk; air 6,68 \%bb; abu $1,89 \%$ bk dan koefisien rehidrasi 3,44. Hasil uji hedonic adalah tekstur 2,2 (agak kenyal); rasa kacang 2,9 (agak terasa); flavor 2,6 (agak enak) dan kesukaan 2,4 (agak disukai). Kesimpulannya, kombinasi perlakuan terbaik dapat diperoleh dari proporsi tepung ubi kayu (tanpa modifikasi) : tepung koro pedang : susu skim sebanyak 60:35:5.

Kata kunci : tepung ubi kayu modifikasi ragi tape, tepung koro pedang, tiwul instan

\section{Abstract}

To determine the best formula and character of instant tiwul made by mocaf flour subtituted with jack bean flour and skimmed milk, we conducted a factorial randomized design experiment. Treatments factors consist of proportion of cassava flour-jack bean flour-skimmed milk $(P ; w / w): P 1=80: 15: 5, P 2=70: 25: 5, P 3=60: 35: 5$ and type of cassava flour modification of $(A): A O=$ unmodified cassava flour, $A 1=$ yeast modified cassava flour. Analyzed variables were 1) phsycochemical properties (water content, ash content, total fat, total protein, rehydration coefficient) and 2) sensory properties. Hedonic test were conducted to determine the level of consumer acceptance of 25 semi-trained panelists. Data were analyzed by F-test and Duncan's Multiple Range Test (DMRT). The best treatment combination in this study was P3AO (cassava flour-jack bean flour-skimmed milk $60: 35: 5$, unmodified cassava flour). Instant tiwul P3AO has $8.84 \%$ (dry basis/db) protein content, $1.66 \%$ db fat content, $6.68 \%$ wb water content, $1.89 \% d b$ ash content, and 3.44 rehydration coefficient. The hedonic test values were texture at 2.2 (somewhat chewy), bean taste at 2.9 (rather noticeably), flavor at 2.6 (rather good), and preference at 2.4 (slightly favored). As conclusion, the best combination was found in unnmodified cassava flour-jack bean flour-skimmed milk at a ratio of $60: 35: 5$.

Keywords : yeast modified cassava flour, jack bean flour, instant tiwul

\section{Pendahuluan}

Tiwul adalah salah satu makanan tradisional yang memiliki karakteristik agak kenyal terbuat dari gaplek ( ubi kayu yang dikeringkan dan dibuat tepung) dan dimakan bersama kelapa parut. Pembuatan tiwul instan berkembang untuk meningkatkan umur simpan dan kesukaannya. Tiwul instan dibuat dari tepung ubi kayu dengan penambahan sedikit air, gula dan garam yang dicampur sampai homogen kemudian dibentuk granula yang selanjutnya dikukus selama 20 - 30 menit (Hidayat et al., 2012). Masalah yang sering dihadapi dalam pembuatan tiwul instan dari ubi kayu iyalah kadar protein yang relatif rendah. Tepung ubi kayu mengandung protein $1,1 \mathrm{~g}$ per $100 \mathrm{~g}$ bahan (Suismono et al., 2006). Menurut Suhardi dan Suhardjo (2006), tiwul yang dibuat dari ubi kayu tanpa penambahan bahan lain mengandung protein $1,65 \%$; lemak $0,45 \%$; kadar abu $1,50 \%$; serat kasar $1,63 \%$ dan air $10 \%$.

Tiwul instan perlu ditingkatkan kandungan kimianya terutama kandungan protein menggunakan tepung sumber protein seperti dari (kacang-kacangan, umbi, sereal dan ikan) (Wardayanie et al., 2008). Agustia et al. (2016) melaporkan bahwa, kacang-kacangan (kacang merah dan kacang hijau) dapat meningkatkan kandungan protein $\mathrm{mi}$ bebas gluten. Penelitian mengenai tiwul instan dengan penambahan sereal dan konsentrat protein kedelai dapat meningkatkan kandungan protein telah dilakukan oleh Rukmini dan Naufalin (2015). Salah satu bahan dari kacangkacangan yang potensial digunakan untuk 
meningkatkan kandungan kimia tiwul instan adalah kacang koro pedang. Kacang koro pedang adalah sumber protein nabati yang kaya akan karbohidrat, rendah lemak, memiliki keseimbangan asam amino yang baik dan memiliki kandungan mineral yang baik untuk kesehatan tubuh. Menurut Sudiyono (2010), dari kandungan gizi, kacang koro pedang memiliki semua elemen gizi dengan kandungan gizi yang cukup tinggi yaitu karbohidrat $60,1 \%$; protein $30,36 \%$ dan serat $8,3 \%$.

Tepung ubi kayu sebagai bahan utama pembuat tiwul instan dapat dibuat dengan metode fermentasi. Pengembangan teknologi pengolahan tepung ubi kayu secara fermentasi telah dilaporkan oleh Subagyo (2006), dalam bentuk mocaf (modified cassava flour). Fermentasi ubi kayu diharapkan dapat meningkatkan nilai gizi tepung yang dihasilkan serta meningkatkan rasa dan mutu yang diinginkan, terkait dengan nilai cerna dan sifat-sifatnya, serta meningkatkan keamanan pangan dari ubi kayu (Uyoh et al., 2009).

Penelitian mengenai penggunaan mocaf untuk produk pangan telah banyak dilakukan salah satunya sebagai bahan dalam pembuatan biskuit mocaf-garut yang disubstitusi hati sebagai alternatif biskuit tinggi zat besi untuk balita (Agustia et al., 2017). Amri and Pratiwi (2014) telah meneliti pembuatan mocaf dengan metode fermentasi menggunakan beberapa tipe ragi. Pada penelitian ini tiwul dibuat menggunakan modifikasi tepung ubi kayu yang berbeda (dengan modifikasi menggunakan ragi tape dan tanpa modifikasi). Beberapa tipe tepung ubi kayu dapat mempengaruhi sifat fisikokimia dan sensori tiwul instan yang dihasilkan.

Bahan pangan lain selain kacang koro pedang yang dapat digunakan untuk meningkatkan kandungan protein tiwul instan ini adalah susu skim. Susu skim merupakan produk susu yang sebagian besar lemaknya telah dihilangkan dan dipasteurisasi atau disterilisasi atau diproses dengan UHT (Ultra High Temperature). Bubuk susu skim 100 gram mengandung energi 362 Kkal, protein 35,6 gram, lemak 1 gram, dan karbohidrat 52 gram (Depkes RI, 2014). Penambahan susu skim juga ditujukan untuk menutupi flavor kacang koro pedang yang kurang disukai.

Pembuatan tiwul instan dari bahan tepung ubi kayu yang disubstitusi tepung koro pedang dan susu skim bertujuan sebagai salah satu upaya diversifikasi pangan berbasis lokal. Oleh karena itu, penelitian ini bertujuan untuk mengetahui berapa proporsi tepung ubi kayu : tepung koro pedang : susu skim dan modifikasi tepung ubi kayu yang tepat untuk menghasilkan tiwul instan dengan kadar protein tinggi dan sifat sensori yang disukai. Manfaat dari penelitian ini ialah untuk melestarikan salah satu pangan tradisional yaitu tiwul yang dibuat dalam bentuk instan sehingga lebih mudah untuk dikonsumsi dan memiliki umur simpan yang lebih lama karena berbentuk kering.

\section{Materi dan Metode Materi}

Bahan yang digunakan dalam penelitian ini ialah ubi kayu (varietas putih) sebagai bahan utama diperoleh dari Pasar Wage Purwokerto, kacang koro pedang diperoleh dari Bogor. Susu skim, gula, agar, baking powder, garam dan vanila diperoleh dari Toko Intisari Purwokerto serta beberapa bahan untuk analisis kimia. Peralatan yang digunakan selama penelitian antara lain peralatan untuk produksi tepung dan tiwul instan termasuk timbangan analitik, oven, blender, ayakan ukuran 60 dan 80 mesh, cetakan mi dan peralatan untuk analisis fisikokimia.

\section{Metode}

Penelitian dilakukan pada Bulan Mei sampai Oktober Tahun 2016 di Laboratorium Pengolahan Pangan Jurusan Teknologi Pertanian Universitas Jenderal Soedirman. Penelitian ini menggunakan rancangan acak kelompok. Faktor perlakuan terdiri dari proporsi tepung ubi kayu - tepung koro pedang - susu skim $(\mathrm{P} ; \mathrm{b} / \mathrm{b}): \mathrm{P} 1=80: 15: 5, \mathrm{P} 2=70: 25: 5, \mathrm{P} 3=60$ : 35 : 5 dan modifikasi tepung ubi kayu $(A): A 0=$ tanpa modifikasi, $\mathrm{A} 1$ = modifikasi dengan ragi tape. Dari dua faktor diperoleh 6 (2x3) perlakuan yaitu P1A0, P1A1, $\mathrm{P} 2 \mathrm{~A} 0, \mathrm{P} 2 \mathrm{~A} 1, \mathrm{P} 3 \mathrm{~A} 0$ and $\mathrm{P} 3 \mathrm{~A} 1$. Tiap perlakuan diulang empat kali sehingga diperoleh 24 kombinasi perlakuan.

Proses Pembuatan Tepung Ubi Kayu Tanpa Modifikasi

Ubi kayu dikupas kemudian diiris menggunakan slicer ukuran $\leq 0,5 \mathrm{~cm}$, selanjutnya dicuci dan di steam blanching selama 15 menit. Proses berikutnya ubi kayu dikeringkan menggunakan pengering kabinet pada suhu $55-60{ }^{\circ} \mathrm{C}$ selama \pm 24 jam atau sampai kering patah. Ubi kayu kering kemudian digiling dan diayak menggunakan ayakan ukuran 80 mesh. Tepung yang lolos ayakan selanjutnya disimpan rapat sampai akan digunakan (Rukmini et al., 2016).

\section{Pembuatan Tepung Ubi Kayu Modifikasi}

Ubi kayu dikupas kemudian diiris menggunakan slicer ukuran $\leq 0,5 \mathrm{~cm}$, selanjutnya dicuci dan di steam blanching selama 5 menit. Proses selanjutnya direndam dalam larutan ragi tape 4\%, $1: 5$ (b/v) selama 6 jam. Kemudian ubi kayu dicuci menggunakan air mengalir sampai $\mathrm{pH}$ nya netral \pm 7 , kemudian di steam blanching selama 5 menit. Proses selanjutnya dikeringkan menggunakan pengering kabinet kabinet pada suhu 55$60{ }^{\circ} \mathrm{C}$ selama \pm 24 jam atau sampai kering patah. Ubi kayu kering kemudian digiling dan diayak menggunakan ayakan ukuran 80 mesh. Tepung yang lolos ayakan selanjutnya disimpan rapat sampai akan digunakan (Rukmini et al., 2016).

\section{Proses Pembuatan Tepung Koro Pedang}

Kacang koro pedang dimasukkan ke dalam kain saring dan diikat menggunakan tali rafia atau karet, kemudian dimasukkan ke dalam larutan $\mathrm{NaOH} 3 \%$ mendidih selama 7 - 8 menit, kemudian dicuci dalam air mengalir sambil diremas-remas sampai pHnya netral. Setelah itu di steam blanching selama 30 menit dan diiris tipis sebelum selanjutnya dikeringkan menggunakan pengering kabinet pada suhu $55-60^{\circ} \mathrm{C}$ selama \pm 24 jam atau sampai kering patah kemudian digiling dan diayak menggunakan ayakan 80 mesh. Tepung yang lolos 
ayakan selanjutnya disimpan rapat sampai akan digunakan (Rukmini et al., 2016).

\section{Pembuatan Tiwul Instan}

Tepung ubi kayu, tepung koro pedang dan susu skim dengan proporsi sesuai dengan perlakuan dicampur rata bersama dengan bahan lain yaitu $0,5 \%$ baking powder; $2 \%$ agar; $20 \%$ gula; $0,5 \%$ vanila; $0,5 \%$ garam dan air hangat sampai adonan berbentuk granula terbentuk. Setelah itu di steam blanching selama 15 menit kemudian dikeringkan menggunakan pengering kabinet pada suhu $55-60^{\circ} \mathrm{C}$ selama \pm 20 hours atau sampai kering patah, lalu tunggu sampai agak dingin dan kemudian dibentuk kembali menjadi granula tiwul instan. Tiwul instan kering kemudian dikemas rapat sampai akan dianalisis. Formula tiwul instan sesuai dengan perlakuan dapat dilihat pada Tabel 1 (Rukmini et al., 2016).

\section{Prosedur Analisa Proksimat}

Analisis yang dilakukan meliputi analisis proksimat yaitu kadar air (metode oven), kadar abu (metode gravimetri), kadar protein (metode microKjeldahl), kadar lemak (metode Soxhlet) dan karbohidrat by difference (Soedarmadji et al., 1997) serta koefisien rehidrasi (Audu dan Aremu, 2011).

\section{Prosedur Analisa Sensori}

Uji sensori dilakukan menurut penelit sebelumnya (Setyaningsih, 2010) yang dilakukan untuk menentukan level penerimaan dari tekstur, rasa kacang, flavor dan kesukaan tiwul instan. Uji hedonik dilakukan pada tiwul instan yang telah dikukus (siap dikonsumsi). Uji dilakukan oleh 25 orang panelis semi terlatih yang sebelumnya diberi pengarahan sehingga mereka paham mengenai parameter yang akan diuji. Uji menggunakan metode skoring. Pengujian ini biasanya menggunakan nilai kuantitatif dengan skor yang telah ditentukan sebelumnya yaitu pada range antara 1 (skor terendah) sampai 4 (skor tertinggi).

\section{Analisis Statistik}

Data dianalisis menggunakan analisis of variance (ANOVA) atau Fishers exact test ( $\mathrm{F}$ test) pada tingkat kepercayaan $95 \%$. Jika berpengaruh nyata, analisis dilanjutkan dengan Duncans Multiple Range Test (DMRT) pada tingkat kepercayaan 5\%.

\section{Hasil dan Pembahasan}

Kadar Abu dan Kadar Abu

Data kadar air dan abu tiwul instan yang disubstitusi tepung koro pedang dan susu skim ditunjukkan pada Tabel 2. Data menunjukkan bahwa proporsi tepung ubi kayu : tepung koro pedang : susu skim (b/b) dan perlakuan modifikasi dengan ragi tape tidak berpengaruh nyata terhadap kadar air tiwul instan. Kadar air tiwul instan berkisar 5,00-8,00\%bb. Hal ini sesuai dengan produk instan lain yaitu mi instan yang disuplementasi serbuk wortel memiliki kadar air 7,75 \%bb (Marliyati et al., 2012).

Kadar air tiwul cukup rendah di bawah 10\% sehingga diharapkan tiwul instan mentah bila dikemas dengan bahan kemas dan metode yang baik akan memiliki masa simpan tinggi. Kisaran kadar air 5,00 $8,00 \% \mathrm{bb}$, nilai ini tidak ditentukan oleh proporsi bahanbahan pembuat tiwul dan adanya pengaruh modifikasi dengan ragi tape terhadap ubi kayu yang digunakan sebagai bahan utama tiwul. Hal ini karena tiwul dibuat dari bahan-bahan tepung ubi kayu, tepung koro pedang, dan susu skim yang kadar air relatif sama-sama rendah. Selain itu hasil cetakan adonan tiwul basah dikeringkan dengan suhu dan metode yang sama, sampai kering patah.

Berbeda dengan kadar air, perlakuan modifikasi dengan ragi tape terhadap ubi kayu berpengaruh sangat nyata $(P<0.05)$ terhadap kadar abu tiwul instan, sedangkan proporsi bahan-bahan pembuat tiwul tidak berpengaruh nyata walaupun ada kecenderungan semakin tinggi proporsi tepung koro pedang semakin tinggi pula kadar abu tiwul instan. Terkait dengan perlakuan modifikasi dengan ragi tape, dari analisis statistik diketahui bahwa kadar abu tiwul instan yang menggunakan ubi kayu tanpa modifikasi mempunyai kadar abu lebih tinggi daripada yang dengan modifikasi. Hal ini kemungkinan besar diakibatkan karena pada pembuatan tepung ubi kayu dengan modifikasi menggunakan ragi tape dengan metode perendaman, sebagian mineral ubi kayu hilang karena melarut ke dalam air ragi perendam ubi kayu. Kadar abu tiwul instan kering hasil penelitian ini berkisar 1,20 - 2,70 \%bk. Kadar abu tiwul instan ini relatif rendah.

\section{Koefisien Rehidrasi}

Koefisien rehidrasi menunjukkan tingginya daya rehidrasi atau pengikatan air tiwul instan saat dimasak. Koefisien rehidrasi yang tinggi berarti tiwul instan mudah

Tabel 1. Formula tiwul instan substitusi tepung koro pedang dan susu skim

\begin{tabular}{lcccccc}
\hline \multicolumn{1}{c}{ Bahan $(\%)$} & $\mathrm{P} 1 \mathrm{~A} 0$ & $\mathrm{P} 1 \mathrm{~A} 1$ & $\mathrm{P} 2 \mathrm{~A} 0$ & $\mathrm{P} 2 \mathrm{~A} 1$ & $\mathrm{P} 3 \mathrm{~A} 0$ & $\mathrm{P} 3 \mathrm{~A} 1$ \\
\hline Tepung ubi kayu tanpa modifikasi & 80 & 0 & 70 & 0 & 60 & 0 \\
Tepung ubi kayu modifikasi ragi tape & 0 & 80 & 0 & 70 & 0 & 60 \\
Tepung koro pedang & 15 & 15 & 25 & 25 & 35 & 35 \\
Susu skim & 5 & 5 & 5 & 5 & 5 & 5 \\
Baking powder & 0,5 & 0,5 & 0,5 & 0,5 & 0,5 & 0,5 \\
Bubuk agar & 2 & 2 & 2 & 2 & 2 & 2 \\
Gula & 20 & 20 & 20 & 20 & 20 & 20 \\
Vanili & 0,5 & 0,5 & 0,5 & 0,5 & 0,5 & 0,5 \\
Garam & 0,5 & 0,5 & 0,5 & 0,5 & 0,5 & 0,5 \\
\hline Jumlah $(\mathrm{g})$ & 123,5 & 123,5 & 123,5 & 123,5 & 123,5 & 123,5 \\
\hline
\end{tabular}


mengikat air, sehingga saat dimasak dengan uap air atau saat dicampur dengan air tekstur mudah lunak, dan tiwul tanak mudah dikunyah. Data hasil koefisien rehidrasi tiwul instan substitusi tepung koro pedang dan susu skim dapat dilihat pada Tabel 2. Rerata koefisien rehidrasi cukup tinggi yaitu berkisar $3-4$. Tingginya daya rehidrasi pada tiwul instan ini berasal dari senyawasenyawa yang mudah mengikat air yang terkandung di dalamnya terutama protein dan pati. Selain itu diakibatkan oleh bubuk agar yang diberikan dalam jumlah relatif tinggi (2\%). Penambahan agar juga dilakukan pada penelitian Alvarenga et al. (2011) yang meneliti pembuatan roti bebas gluten dari campuran tepung beras, tepung jagung dan tapioka sebagai matriks untuk meniru sifat gluten.

Rukmini dan Naufalin (2015) menyatakan koefisien rehidrasi tiwul instan yang disubstitusi tepung lembaga serealia dan konsentrat protein kedelai berkisar $2-4$, sedangkan menurut Nurbani et al. (2008), beras instan yang dibuat dari tepung gaplek - tepung ubi jalar $50: 50 \mathrm{~b} / \mathrm{b}$ mempunyai tingkat rehidrasi $38,13 \%$.

\section{Kadar Protein dan Lemak}

Data kadar protein dan lemak tiwul instan substitusi tepung koro pedang dan sisi skim dapat dilihat pada Tabel 2. Data penelitian menunjukkan bahwa

Tabel 2. Data ANOVA (uji F) dan DMRT pada level 5\% sifat fisikokimia tiwul instan

\begin{tabular}{lccccc}
\hline Data & $\begin{array}{c}\text { Koefisien } \\
\text { rehidrasi }\end{array}$ & $\begin{array}{c}\text { Kadar abu } \\
(\% \mathrm{bk})\end{array}$ & $\begin{array}{c}\text { Kadar Air } \\
(\% \mathrm{bb})\end{array}$ & $\begin{array}{c}\text { Kadar } \\
\text { Protein } \\
(\% \text { bk })\end{array}$ & $\begin{array}{c}\text { Kadar } \\
\text { Lemak } \\
(\% \text { bk })\end{array}$ \\
\hline $\begin{array}{l}\text { Proporsi Tepung Ubi Kayu : Tepung Koro } \\
\text { Pedang : Susu Skim (P) }\end{array}$ & & & & & \\
P1 & $4.02 \mathrm{a}$ & 1.51 & 6.12 & 6.21 & 1.18 \\
P2 & $3.82 \mathrm{ab}$ & 1.57 & 6.24 & 8.36 & 1.25 \\
P3 & $3.66 \mathrm{~b}$ & 1.71 & 6.63 & 9.76 & 1.12 \\
Modifikasi Tepung Ubi Kayu (A) & & & & & \\
A0 & $3.57 \mathrm{~b}$ & $1.79 \mathrm{a}$ & 6.30 & 6.41 & 1.28 \\
A1 & $4.09 \mathrm{a}$ & $1.40 \mathrm{~b}$ & 6.35 & 6.72 & 1.31 \\
Interaksi Keduanya (PxA) & & & & & \\
P1A0 & 3.71 & 1.84 & 6.22 & 6.34 & 1.36 \\
P1A1 & 4.32 & 1.18 & 6.25 & 8.28 & 1.17 \\
P2A0 & 3.57 & 1.63 & 6.26 & 9.70 & 1.64 \\
P2A1 & 4.06 & 1.52 & 6.22 & 6.18 & 0.82 \\
P3A0 & 3.44 & 1.89 & 6.67 & 8.84 & 1.66 \\
P3A1 & 3.88 & 1.52 & 6.59 & 10.91 & 1.43 \\
\hline Kerand
\end{tabular}

Keterangan:

Angka yang diikuti huruf yang sama tidak berbeda nyata ( $p>0,05$; DMRT $5 \%$ )

A0 : Tanpa Modifikasi

A1 : Modifikasi Dengan Ragi Tape

P1 : Tepung Ubi Kayu : Tepung Koro Pedang: Susu Skim $=80: 15: 5$

P2 : Tepung Ubi Kayu : Tepung Koro Pedang : Susu Skim $=70: 25: 5$

P3 : Tepung Ubi Kayu : Tepung Koro Pedang : Susu Skim $=60: 35: 5$

Tabel 3. Data ANOVA (uji F) dan DMRT pada level 5\% sifat sensori tiwul tnstan

\begin{tabular}{|c|c|c|c|c|}
\hline Data & Tekstur & Rasa Kacang & Flavor & Kesukaan \\
\hline \multicolumn{5}{|c|}{ Proporsi Tepung Ubi Kayu : Tepung Koro Pedang : Susu } \\
\hline \multicolumn{5}{|c|}{ Skim $(P)$} \\
\hline P1 & 2,3 & $2,1 \mathrm{~b}$ & 2,3 & 2,3 \\
\hline $\mathrm{P} 2$ & 2,4 & $2,1 \mathrm{~b}$ & 2,3 & 2,4 \\
\hline P3 & 2,3 & $2,6 \mathrm{a}$ & 2,3 & 2,2 \\
\hline \multicolumn{5}{|l|}{ Modifikasi Tepung Ubi Kayu (A) } \\
\hline AO & 2,4 & 2,4 & 2,6 a & $2,5 \mathrm{a}$ \\
\hline A1 & 2,3 & 2,2 & $2,0 \mathrm{~b}$ & $2,0 \mathrm{~b}$ \\
\hline \multicolumn{5}{|l|}{ Interaksi Keduanya (PxA) } \\
\hline $\mathrm{P} 1 \mathrm{~A} 0$ & 2,6 & 2,0 & 2,5 & 2,5 \\
\hline $\mathrm{P} 1 \mathrm{~A} 1$ & 2,1 & 2,1 & 2,0 & 2,0 \\
\hline $\mathrm{P} 2 \mathrm{~A} 0$ & 2,4 & 2,2 & 2,7 & 2,7 \\
\hline $\mathrm{P} 2 \mathrm{~A} 1$ & 2,4 & 2,1 & 1,9 & 2,1 \\
\hline P3A0 & 2,2 & 2,9 & 2,6 & 2,4 \\
\hline P3A1 & 2,4 & 2,3 & 2,0 & 2,1 \\
\hline
\end{tabular}

Keterangan:

Angka yang diikuti huruf yang sama tidak berbeda nyata ( $p>0.05$; DMRT $5 \%$ )

A0 : Tanpa Modifikasi

A1 : Modifikasi Dengan Ragi Tape

P1 : Tepung Ubi Kayu : Tepung Koro Pedang : Susu Skim $=80: 15: 5$

P2 : Tepung Ubi Kayu : Tepung Koro Pedang: Susu Skim $=70: 25: 5$

P3 : Tepung Ubi Kayu : Tepung Koro Pedang : Susu Skim $=60: 35: 5$ 
kadar protein tiwul instan berkisar 6,18 - 10,91 \%bk. Kadar protein tiwul instan yang diperoleh ini cukup tinggi. Kandungan protein tiwul yang tinggi diberikan oleh kacang koro pedang yang mengandung protein berkisar $27-30 \%$. Ini pula yang menyebabkan kadar protein tiwul instan meningkat dengan meningkatnya proporsi tepung koro pedang yang digunakan. Agustia et al. (2016) melaporkan tiwul instan yang disubtitusi tepung koro pedang pra germinasi $25 \%$ memiliki kadar protein sebesar $6.24 \%$ bk.

Sebaliknya kandungan lemak tiwul instan rendah, berkisar 0,82-1,66 \%bk (Tabel 3). Hal ini diakibatkan oleh kandungan lemak tepung ubi kayu yang sangat rendah, sebesar 1,1\% (Direktorat Gizi Depkes RI, 1992), demikian pula koro pedang, kadar lemaknya rendah berkisar $3-4 \%$ (Doss et al., 2011), selain itu juga diakibatkan oleh proporsi susu skim (rendah lemak) yang digunakan hanya $5 \%$.

\section{Tekstur atau Kekenyalan Tiwul instan tanak}

Kekenyalan tiwul tanak merupakan sifat sensori terpenting. Sifat kenyal yang dikehendaki adalah sifat "agak kenyal" bukan sifat kenyal seperti yang ada pada permen jelly, permen karet ataupun mie rebus kenyal. Skor nilai yang dikehendaki berada diantara 2 (agak kenyal) dan 3 (kenyal) atau disekitar 2 (agak kenyal). Sifat kekenyalan tiwul diberikan oleh hasil gelatinisasi pati dan penambahan bubuk agar yang sengaja ditambahkan pada adonan tiwul. Menurut penelitian Rukmini dan Naufalin (2015), penambahan bubuk agar sejumlah $1,25 \%$ dapat meningkatkan kekenyalan tiwul instan 3,13 (kenyal).

Hasil analisis statistik (Tabel 3) menunjukkan bahwa baik perlakuan modifikasi dengan ragi tape terhadap ubi kayu maupun perlakuan proporsi tepung ubi kayu-tepung koro pedang-susu skim tidak berpengaruh nyata terhadap tekstur tiwul instan tanak. Tiwul tanak mempunyai skor tekstur berkisar 2,10-2,55 (agak kenyal). Walaupun ada kecenderungan bahwa tiwul tanak dari penggunaan tepung ubi kayu tanpa modifikasi lebih kenyal (nilai tekstur 2,4) daripada yang dengan modifikasi (nilai tekstur 2,3) kemungkinan tiwul dengan tepung ubi kayu hasil modifikasi sebagian pati sudah mengalami hidrolisis menjadi senyawa-senyawa dengan berat molekul rendah yang berarti jumlah pati yang tergelatinisasi berkurang. Menurut Agustia et al. (2016), tiwul instan yang disubstitusi tepung koro pedang pragerminasi memiliki tekstur dengan kisaran 1,40 2,87 (agak kenyal - kenyal).

\section{Rasa khas kacang tiwul instan}

Hasil analisis statistik terhadap rasa khas kacang pada tiwul tanak menunjukkan bahwa proporsi pembuat tiwul, tepung ubi kayu-tepung koro pedang - susu skim, berpengaruh sangat nyata terhadap rasa khas kacang, sedangkan perlakuan modifikasi dengan ragi tape tidak berpengaruh nyata. Proporsi tepung ubi kayu-tepung kacang koro pedang - susu sikim $80: 15: 5 ; 70: 25: 5$ $; 60: 35: 5$ berturut-turut menghasilkan tiwul dengan nilai rasa khas kacang 2,$1 ; 2,1 ; 2,6$. Rasa tiwul tanak dari proporsi $80: 15: 5$ tidak berbeda dengan yang dari 70 :
25 : 5 (sama-sama "agak terasa"), sedangkan yang dibuat dengah proporsi $60: 35: 5$ (proporsi tepung koro tinggi) tiwul tanak mempunyai nilai rasa khas kacang 2,6 (terasa). Doss et al. (2011) menyatakan, rasa kacang yang tidak enak disebabkan oleh aktivitas enzim lipoxygenase yang ditemukan secara alami pada bahan (kacang koro pedang).

\section{Flavor Tiwul}

Flavor (cita rasa) tiwul tanak ternyata sangat dipengaruhi oleh perlakuan modifikasi dengan ragi tape. Hasil uji oleh tim panelis menunjukkan bahwa perlakuan modifikasi dengan ragi tape menurunkan nilai flavor tiwul tanak. Nilai flavor tiwul tanak dari penggunaan tepung ubi kayu tanpa modifikasi dengan ragi tape sebesar 2,6 (enak) sedangkan yang dengan tepung ubi kayu modifikasi nilai flavor 2,0 (agak enak).

Flavor "agak enak" pada tiwul instan tanak yang menggunakan tepung ubi kayu hasil modifikasi dengan ragi tape tampaknya diakibatkan oleh adanya senyawasenyawa hasil samping proses metabolisme ragi tape pada ubi kayu. Kemungkinan senyawa - senyawa ini dapat dikurangi dengan pencucian dengan air berulang kali atau mungkin dapat dicoba mencuci ubi kayu iris setelah proses modifikasi dengan ragi tape menggunakan larutan garam dapur konsentrasi rendah (sekitar 5\%). Seperti penelitian Ariefta et al. (2016), penambahan ragi pada ubi jalar yang difermentasi akan meningkatkan nilai total asam. Peningkatan total asam ini disebabkan oleh produksi asam organik sebagai hasil akhir fermentasi. Hal ini menyebabkan tiwul instan yang dibuat dari tepung ubi kayu (tanpa modifikasi) lebih diterima oleh konsumen. Untuk mengurangi atau menutup rasa yang kurang enak juga dapat dilakukan dengan menambahkan zat flavor pada adonan tiwul seperti vanili, caramel dan mocca. Nilai flavor tiwul berkisar 1,90 (agak enak) - 2,70 (enak)

\section{Kesukaan Tiwul Instan Tanak}

Nilai kesukaan terhadap tiwul tanak ternyata sangat dipengaruhi oleh perlakuan modifikasi dengan ragi tape terhadap ubi kayu iris. Tiwul tanak yang dibuat dengan menggunakan tepung ubi kayu yang dihasilkan dari ubi kayu tanpa modifikasi mempunyai nilai kesukaan (nilai kesukaan 2,5) lebih tinggi daripada yang menggunakan tepung hasil modifikasi (nilai kesukaan 2,0).

Nilai kesukaan ternyata sejalan dengan nilai flavor tiwul. Nilai flavor tiwul yang rendah ternyata nilai kesukaan juga rendah. Nilai kesukaan terhadap tiwul berkisar 2,00 (agak suka) - 2,65 (suka).

\section{Kesimpulan}

Kombinasi perlakuan terbaik diperoleh dari P3AO yaitu tiwul instan dengan proporsi tepung ubi kayu (tanpa modifikasi) : tepung koro pedang : susu skim (60:35:5) dengan kadar protein relatif tinggi yaitu $8,84 \%$ bk. Tiwul instan memiliki sifat sensori yang baik dengan koefisien rehidrasi yang tinggi $(3,44)$. Saran untuk penelitian berikutnya terutama untuk penambahan flavoran misalnya karamel atau moka untuk menutupi rasa 
kacang sehingga akan meningkatkan kesukaan terhadap tiwul instan.

\section{Ucapan Terima Kasih}

Peneliti penyampaikan penghargaan yang tinggi dan terima kasih kepada Kementerian Pendidikan dan Kebudayaan yang telah membiayai penelitian ini melalui program Strategi Nasional Tahun 2016 dengan SK Ketua LPPM Unsoed Nomor : Kept. 3021/UN23.14/PN.01.00/2016.

\section{Daftar Pustaka}

Agustia, F.C., Rukmini, H.S., Naufalin, R. 2016. Utilization of pregerminated jackbean and soybean for increasing the protein content of instant tiwul. Proceeding. 162-169. ISBN : 978602-61032-1-5.

Agustia, F.C., Subardjo, Y.P., Sitasari, S. 2016. Formulasi dan karakterisasi mi bebas gluten tinggi protein berbahan pati sagu yang disubstitusi tepung kacang-kacangan. Jurnal Gizi dan Pangan 11(3):183-190. DOI: 10.25182/jgp.2016.11.3.\%25p.

Agustia, F.C., Subardjo, Y.P., Sari, H.P. 2017. Pengembangan biskuit mocaf-garut dengan substitusi hati sebagai alternatif biskuit tinggi zat besi untuk balita. Journal of Nutrition and Food 12(2):129-138, 10.25182/jgp.2017.12.2.129-138.

Alvarenga, N.B., Lidon, F.C., Belga, E., Motrena, P., Guerreiro, S., Joao, M. 2011. Characterization of gluten free bread prepared from maize, rice and tapioka flours using the hydrocolloid seaweed agar-agar. Recent Research in Science and Technology 3(8):64-68.

Amri, E., Pratiwi, P. 2014. Pembuatan mocaf (Modified Cassafa Flour) dengan proses fermentasi menggunakan beberapa tipe ragi. Jurnal Pelangi : Research and Education Development 6(2): 182 - 191 DOI: 10.22202/jp.2014.v6i2.302.

Ariefta, G.A., Putra, G.G., Anggraeni, A.D. 2016. Pengaruh penambahan ragi tape dan waktu fermentasi terhadap karakteritik pulpa biji kakao. Jurnal Rekayasa dan Manajemen Agroindustri 4(2):42-52.

Audu, S.S., Aremu, M.O. 2011. Effect of processing on chemical composition of red kidney bean (Phaseolus vulgalris L.) flour. Pakistan Journal Nutrition 10(11):1069-1075. DOI: 10.3923/pin.2011.1069.1075.

Depkes RI. 2014. Komposisi Produk Pangan. Diakses Desember,19 2016.

Doss, A., Pugalenthi, M., Vadivel, V.G., Subhashini, G., Anitha. 2011. Effect of processing technique on the nutritional composition and antinutrients content of under utilized food legume canavalia ensiformis L. DC. International Food Research Journal 18(5): 965-970.
Hidayat, N., Nurika, I., Purwningsih, I., Eva, N.W. 2012. A Studi of consumers acceptance Instant Tiwul and its financial analysis. J Agric Food Tech. 2 (12) : 178-183.

Marliyati, S.A., Sulaeman, A., Rahayu, M.P. 2012. Aplikasi Serbuk Wortel Sebagai Sumber BKaroten Alami Pada Produk Mi Instan. Jurnal Gizi dan Pangan 7(2): 127-134. DOI: 10.25182/jgp.2012.7.2.127-134

Nurbani, K., Hidayat, B., Sufriana. 2008. Kajian Optimasi Proses Pengolahan Produk Beras Instan Ubi Jalar (Ipomoea batata L.) varietas Shiroyutaka. J Teknologi Ind hasil Pertanian. 13(2) : 85 - 94.

Rukmini, H.S., Purbowati, I.S.M., Agustia, F.C. 2016. Produksi Tiwul Instan Tinggi Gizi dari Tepung Komposit Berbahan Utama Tepung Ubi Kayu Termodifikasi dan Evaluasi Mutu Produk. Laporan Penelitian Strategis Nasional, DP2M Dikti.

Rukmini, H.S., Naufalin, R. 2015. Formulasi Tiwul Instan Tinggi Protein Melalui Penambahan Lembaga Serealia dan Konsentrat Protein Kedelai. Jurnal Teknologi Industri Pertanian. 25(3): 190-197.

Setyaningsih, D., Apriyantono, A., Sari, M.P. 2010. Analisis Sensori untuk Industri Pangan dan Agro. IPB Press, Bogor.

Subagyo, A. 2006. Pengembangan Tepung Ubi Kayu sebagai Bahan Industri Pangan. Seminar Rusnas Diversifikasi Pangan Pokok Industrialisasi Diversifikasi Pangan Berbasis Potensi Pangan Lokal. Kementrian Ristek dan Seafast Center. IPB. Serpong.

Sudarmaji, S., Bambang, H., Suhardi. 1997. Prosedur analisa untuk bahan makanan dan pertanian. Yogyakarta: Liberty.

Sudiyono. 2010. Penggunaan $\mathrm{NaH}_{2} \mathrm{CO}_{3}$ untuk mengurangi kandungan asam sianida $(\mathrm{HCN})$ koro bengkuk pada pembuatan koro bengkuk goreng. Agrika 4(1):48-53.

Suhardi, Suhardjo. 2006. Teknologi produksi tiwul instan dari tepung ubi kayu komposit. Info Teknologi Pertanian No.27 Tahun 2006. Balai Pengkajian Teknologi Pertanian. Jawa Timur.

Suismono, Hadi, S., Widiowati. 2006. Pembuatan tepung kasava. Penerbit Balai Besar Penelitian dan Pengembangan Pascapanen Pertanian.

Uyoh, E.A., Ntui, V.O., Udoma, N.N. 2009. Effect of local cassava fermentation methods on some physiochemical and sensory properties of fufu. Pakistan Journal of Nutrition 8(8): 1123-1125. DOI: 10.3923/pin.2009.1123.1125.

Wardayanie, N.I.A., Susanti, I., Aviana, T., Herman, A.S. 2008. Potensi umbi-umbian dan serealia dalam menunjang diversifikasi pangan berbasis sumber daya lokal. Jurnal Riset Industri $2(1): 35-43$. 